\title{
El modo verbal y las estructuras dialógicas asociadas a la pragmática como recurso dramatúrgico
}

\author{
A dramaturgical resource: the verbal mode and the dialogical structures \\ associated with pragmatics \\ Eduardo de ÁGREDA COSO ${ }^{1}$ \\ Universidad Complutense de Madrid (España)
}

\begin{abstract} resource.

Keywords: Dialogue, dialogical mode, pragmatics, plays, dramaturgical resource

Resumen

1 (D) https://orcid.org/0000-0003-4943-4697

Universidad Complutense de Madrid (UCM)

Centro Complutense para la Enseñanza del Español (CCEE- UCM)

egacoso@ucm.es
\end{abstract}

Dialogue and pragmatics are two widely connected spheres. On many occasions, they are interrelated in the creation of real discourse. Several of the structures most closely linked to the dialogic mode or dialogue are analysed in order to study their relationship with pragmatic definitions. Finally, the search for these exponents is broadened in some current plays written in the Spanish language, defining their type of use both in following up on pragmatic recommendations and in contesting them; as well as the analysis of these items as a dramaturgical

El diálogo y la pragmática son dos esferas o competencias ampliamente conectadas. Cada uno de estos campos, en muchas ocasiones, se interrelacionan en la creación de discurso real. Analizaremos varias de las estructuras más vinculadas al modo dialógico o diálogo para estudiar su relación con las definiciones de tipo pragmático. Finalmente, ampliamos la búsqueda de estos exponentes en algunas obras teatrales actuales escritas en lengua española definiendo su tipo 
de uso tanto en el seguimiento de las recomendaciones pragmáticas como en la ruptura de éstas; así como el análisis de estos ítems como recurso dramatúrgico.

Palabras clave: Diálogo, modo dialógico, pragmática, obras teatrales, recurso dramatúrgico

\section{Introducción}

La oralidad y la pragmática, entendidas como competencias generadoras de discurso real, cuyas vinculaciones con el diálogo comunicativo están lejos de ser escasas, están ampliamente interrelacionadas. El amplio campo de deícticos en los que se insertan los parámetros del modo dialógico, hacen aún más patente esta relación de competencias. Pero este es solo un ejemplo. Muchos de los principios defendidos y analizados por los estudios pragmáticos de los SS XX y XXI se fundamentan en la creación o existencia de diálogo real. Cuando nos referimos a la palabra real, desde un punto de vista literario y/o escrito, hacemos referencia a ese diálogo que pretende tener un reflejo vivo para aquel que lo escucha. Esta "realidad deseada" es la que se da en la creación de muchos diálogos y es la que persigue cualquier obra de teatro actual o de épocas anteriores. Por ello, no es nuestro objetivo ahondar en los diferentes tipos de textos teatrales creados a lo largo de la historia y las divisiones y subdivisiones que existen entre aquellos textos puramente dramáticos y otros más relacionados con la lectura o, como alguna vez se mencionaba, las "novelas dialogadas"2. Sí lo será, en cambio, analizar y descubrir aquellos exponentes claramente dialógicos, dentro de varios ejemplos de algunas obras de teatro españolas actuales, y su vinculación con la competencia y definiciones pragmáticas. No es éste un intento de estudio semiótico, más centrado en el texto de tipo espectacular que se desliza de todo texto teatral (literatura y espectáculo), sino una investigación puramente lingüística en relación con sus vinculaciones pragmáticas y dialógicas. Sin embargo, y por suponer el territorio de la semiótica una esfera ampliamente relacionada con el signo lingüístico, esto no significará que puedan existir

\footnotetext{
2 Así se mencionaba sucesivas veces a las obras de Jacinto Benavente. Por supuesto, nosotros no estamos de acuerdo con esta definición en el teatro del Premio Nobel pues entendemos que, aunque el diálogo es un pilar fundamental -a veces el único- de su teatro, muchas de sus obras pueden ser recibidas como teatro de acción según la diferente óptica de lector o director de escena que se precie. Es por ello que huimos de la posibilidad de analizar qué es teatro con base a la creación de diálogo cuya pretensión sea puesta en escena -y no solo como artículo de lectura- y qué no es teatro.
} 
análisis por nuestra parte susceptibles de ser considerados pertenecientes a esta materia. En este trabajo, primero estudiaremos de manera genérica cuáles son las relaciones entre el diálogo y la pragmática; y algunos estudios que han analizado esta relación; después plantearemos varias de las estructuras lingüísticas consideradas más cercanas al mundo del diálogo (y relacionadas con el modo verbal y dialógico) con base en la Nueva Gramática de la RAE (2011) por considerar esta obra, en cuanto a su calidad y actualidad, una muestra fiable desde un punto de vista de rastreo de exponentes dialógicos. En tercer lugar, ahondaremos en qué tipo de aspectos o definiciones de tipo pragmático pueden activar estas estructuras del diálogo reflejándolas con ejemplos y contraejemplos (pues los exponentes dialógicos pueden, por supuesto, generar ruptura de ítems de la pragmática como pueden ser las máximas, los tipos de contextos, etc.) en obras teatrales actuales escritas en lengua española.

\subsection{Relaciones entre el diálogo y la pragmática}

\subsubsection{Características generales del diálogo}

¿Están relacionadas las esferas del diálogo y de la pragmática? Y, si es así ¿de qué modo? Antes de poder responder a cualquiera de estas preguntas, hemos de definir, en primer lugar, qué significa por un lado diálogo y por otro lado la pragmática. Son muchos los estudios y definiciones relacionados con una y otra esfera. Definiremos brevemente, pues por cuestiones de tiempo y espacio podríamos abarcar una gran investigación y no es éste nuestro objetivo, qué significa el diálogo. Si consultamos varios diccionarios como el de María Moliner, el diccionario de la Real Academia Española, o el de la Lengua Española de la editorial Espasa Calpe coinciden sus definiciones en varios matices: la acción de hablar con otras dos o más personas, contestando cada una a lo que otra ha dicho antes (Moliner), que intercambian el turno de palabra (Espasa- Calpe), mostrando sus ideas o afectos (DRAE) o que discuten sobre sus puntos de vista intentando llegar a un acuerdo (las tres obras). El discurso verbal en la comunicación cotidiana adopta dos vértices: el monólogo, donde alguien habla y es escuchado en silencio por otro/s donde el discurso lo realiza un solo emisor y el diálogo que conlleva una cadena de intervenciones lingüísticas que se producen en progresivo presente, con los interlocutores asumiendo el papel de emisor y receptor continuamente y expresándose directamente. Dentro de las tres perspectivas que recoge Bobes Naves (1992: 7) sobre cómo se puede analizar el diálogo (1) como proceso interactivo, fundamentando en las relaciones sociales, verbales o no, del hombre y como tal puede ser objeto de una pragmática; 2) como una construcción verbal, objeto 
de una investigación lingüística y 3) como recurso literario) nuestro estudio se centrará en las dos primeras sin, por ello, traspasar a veces las fronteras del discurso dialógico como literatura debido a que las muestras analizadas son literatura.

Hoy en día, el diálogo supone un recurso que se despliega por varias vertientes relacionadas con el ser humano: en el plano político es de vital importancia la presencia del diálogo (diálogos occidente- oriente, en las instituciones mundiales como la OMS, la ONU, etc.) planteando las reglas basadas en los preludios, las condiciones, las implicaciones conversacionales, los tiempos y espacios adecuados, los interlocutores, los temas, etc. En otras disciplinas como el campo del conocimiento y de la epistemología (con relación a las justificaciones filosóficas del conocimiento objetivo de la realidad) o de la sociología, por la influencia de la interacción social, el diálogo se plantea como una cuestión fundamental. Otras disciplinas como la Semiología general, la Lógica matemática, o la Filosofía del Lenguaje estudian el diálogo desde diferentes vértices. Por supuesto, y como hemos mencionado más arriba, el diálogo tiene un impacto especial en la disciplina de la Pragmática pues no se circunscribe a hechos obligatoriamente lingüísticos, sino que concibe también el mundo de las circunstancias personales de los hablantes y las referencias contextuales e intertextuales donde se desarrolla. El diálogo, además, se vincula de manera especial, por ser el uso verbal que mejor se presta a ello, al estudio de las ciencias pertenecientes al lenguaje no verbal como pueden ser la kinésica, la proxémica, la paralingüística y las referencias intertextuales relacionadas con en lenguaje en situación (o "en directo"), la comunicación directa del aquí y el ahora, etc.

Por último, recogemos algunas de las características principales que han de darse en todo diálogo:

1. Es una actividad social: formado en la sociedad, por y para la sociedad. Su base constructivista en relación a los principios que defendió Vygotsky (1934) - diálogo, cultura, mediación, uso de herramientas, etc.-, es clara y manifiesta.

2. Es una actividad sémica cuyo sentido discursivo se da gracias a más de un hablante, donde se da un intercambio de signos verbales y no verbales concurrentes; además, hay un proceso de interpretación de todos "los actores" para poder intervenir que hacen posible el diálogo. Es un proceso desde dentro hacia fuera, donde hay un análisis de contexto social y de situación en la que se desarrolla el diálogo. 
3. Es una actividad realizada por dos o más hablantes (de forma interactiva), donde cada interlocutor cuenta con la intervención del otro para preparar la propia intervención y donde es preciso tener en cuenta las palabras utilizadas, el uso, el tono, los gestos, distancia, etc. Realizan sendas funciones de emisor y receptor.

4. La situación comunicativa es cara a cara ${ }^{3}$.

5. Debe haber una actitud de colaboración: en unidad de tema y fin ${ }^{4}$.

6. Se realiza en tiempo presente. Otros tipos de procesos verbales no se construyen en presente, pueden estar acabados e incluso plantearse por turnos: el ejemplo puede ser una comunicación delegada o representada donde los interlocutores se limitan a decir lo que pueden o se les ha autorizado.

\subsubsection{Características generales de la Pragmática}

Son varias las definiciones que se han dado a un término, y si se nos permite la licencia, tan escurridizo a la hora de establecer su alcance y sus límites 5 . Al igual que con el diálogo, no es nuestra intención hacer una definición completa de la Pragmática ni de todos sus elementos pero sí es necesario desarrollar las líneas generales de este concepto, aunque sea de manera acotada y tal vez más amplia que en el caso del diálogo - por proponer un numeroso abanico en las relaciones pragmático dialógicas-, para poder valorar sus relaciones interdependientes con el diálogo. Comenta Escandell (2005, pp. 15-16) que la pragmática se centra en "el estudio de los principios que regulan el uso del lenguaje en la comunicación, es decir, las condiciones que determinan tanto el empleo de un enunciado concreto por parte de un hablante concreto en una situación comunicativa concreta, como su interpretación por parte del destinatario". En este caso, y poniendo frente a frente la competencia del diálogo con la de la pragmática, el diálogo se relacionaría con el contenido comunicado y la pragmática con la forma de comunicar ese contenido pero

\footnotetext{
3 Significando que, aunque los sujetos que dialogan puedan encontrarse lejos espacialmente hablando (por ej. en una llamada telefónica, una videoconferencia, etc.), la intercambiabilidad de los roles (emisor y receptor), la retroalimentación y el intercambio continuo es necesaria para que se produzca diálogo.

${ }^{4}$ Entendemos como actitud de colaboración el hecho de transmitir un mensaje que ha de ser escuchado, continuado, planteado, finalizado y/ o replicado, etc. por dos o más sujetos.

${ }^{5}$ Así, Levinson (1983: 5) comentaba algunas afirmaciones respecto a la ardua tarea de definir este término, como por ejemplo: "esta definición no es nada fácil de proporcionar, así que manejaremos cierto número de posibilidades (...). Puede ser desconcertante la diversidad de posibles definiciones y de límites claros $(\ldots)$ "
} 
ambas traspasarían sus esferas continuamente enriqueciéndose mutuamente. La misma autora explica que los factores extralingüísticos suponen un factor esencial de la pragmática así como los conceptos emisor, destinatario, intención comunicativa, contexto verbal, situación o conocimiento del mundo.

Otras definiciones interesantes son las de Reyes (1995, pp. 7-8), cuando habla de la pragmática, con relación al campo dialógico y semántico, como "los procesos por medio de los cuales los seres humanos producimos e interpretamos significados cuando usamos el lenguaje." Es decir, el estudio del lenguaje en uso.

Levinson (1983: pp. 5-6), desde un enfoque sintáctico, proponía, entre otras posibles, la siguiente definición: "la pragmática es el estudio de aquellos principios que explican por qué ciertas oraciones son anómalas o no son enunciados posibles". La pragmática, para Levinson, también respondería a la habilidad del ser humano en realizar cálculos instantáneos en la producción e interpretación del lenguaje en su uso ordinario. Para participar en el uso ordinario del lenguaje, uno tiene que ser capaz de hacer tales cálculos tanto en la producción como en la interpretación.

Por último, Yule (2008: 131) se refiere a esta competencia como el "estudio del significado "invisible": la manera en que reconocemos lo que alguien quiere decir o escribir... Nuestras asunciones de lo que el hablante quiere decir y no solo el significado literal son decisivas para entender la comunicación”. En esta línea, nos comenta Gutiérrez Ordóñez (2005: 26) que la disciplina de la pragmática "desarrolla el valor comunicativo del lenguaje, tratando de explicar los mensajes no solamente desde el código, sino desde todas las instancias del acto comunicativo (emisor, destinatario, canal, contexto, etc.)" incorporando la dimensión social del lenguaje o su carácter psicológico entroncando con las disciplinas de la psicología evolutiva, la social y la cognitiva.

Comprendemos tres factores de base en las relaciones pragmáticadiálogo: 1) el diálogo es un proceso interactivo de varios sujetos con carácter social e inscrito en una normativa que regula la actividad dialogal; 2) la presencia de los turnos; 3) el diálogo como creación simultánea hacia la unidad de sentido. Existen unos elementos constantes que aparecerán en un esquema general del diálogo (Regueiro 2004: 4):

1. Cada sujeto aporta su propio rol, su función específica y su modo de actuar lingüísticamente.

2. A los actos verbales hay que añadir las acciones no verbales de los sujetos que están en la situación. 
3. El carácter de la misma situación puede dar lugar a diálogos científicos, filosóficos, literarios, etc.

4. El progreso del diálogo, según la secuencia de las intervenciones puede estar en relación con una situación distendida, tensa, dramática, etc.

A estos puntos hay que añadir varios de los conceptos principales de la pragmática que tienen una incidencia destacada en la creación del diálogo ${ }^{6}$ :

A) Principio de cooperación: Grice (1975) propone una principio parecido al de la sinceridad de Searle (1969) consistente en la aplicación u observancia de varias máximas cuyo objetivo final es hacer la comunicación más fluida, respetuosa, clara y económica. Estas son: máxima de cantidad (que la cantidad sea informativa con base a todo lo que necesite el propósito y no se exceda no más de lo necesario), máxima de cualidad (que no se digan cosas falsas o de lo que no se tengan suficientes pruebas), máxima de relación (que se digan cosas relevantes y que se esperan en la conversación) y máxima de modalidad (ser claro, huir de las ambigüedades, de la oscuridad, tener brevedad y orden).

B) Siguiendo a Grice, y vinculado al principio de las implicaturas ${ }^{7}$, el no cumplimiento de estas máximas llevaría a la violación de ellas provocando los siguientes resultados: violación encubierta (cuando el hablante es responsable de engañar), supresión abierta (cuando el interlocutor se niega a seguir participando en el diálogo), conflicto o choque (cuando las máximas rivalizan entre sí y se ha de elegir entre unas u otras) y desprecio de las máximas (cuando se violan las máximas de una forma deliberada).

\footnotetext{
${ }^{6}$ Aunque en este punto cabe preguntarse qué principios de la pragmática son los que no tiene un impacto de profundidad en el diálogo. Por nuestra parte pensamos que pocos o ninguno. Sin embargo, por razones de espacio y acotación, mencionaremos estos ejemplos al considerarlos esenciales en nuestro estudio.

7 Toda esa información que no se dice, sino que "se comunica" es la que recibe una fuerza implícita y se divide en convencionales y no convencionales (cuya diferencia básica es la derivación directa e indirecta, respectivamente, de los significados de las palabras). Las segundas forman un grupo bastante amplio con las implicaturas conversacionales (asociadas a los principios que rigen la conversación - principio de cooperación y las máximas; y que se fraccionan a su vez en generalizadas - que no dependen de forma directa del contexto comunicativo - y particularizadas - sí dependientes del contexto), y las no conversacionales (asociadas a conceptos diferentes como lo cultural, lo social o lo moral, etc.).
} 
C) Dentro de los componentes básicos de la pragmática, queremos prestar especial atención a los contextos, también llamados entornos. El "lugar comunicativo" donde se realiza el acto del diálogo. Atendemos a diferentes tipos de contextos como son el físico (aquel que se vincula al diálogo que denota acciones físicas, la paralingüística, lo que se ve, etc.), el empírico (relacionado con los hechos científicos, objetivos, probados a través de la experiencia), natural (la totalidad de los contextos empíricos), práctico (relacionado con la practicidad del discurso), histórico (son las circunstancias de la historia conocidas por el hablante que pueden englobar tanto su historia personal como la historia de una nación) y cultural (todo lo relacionado con la tradición cultural de una comunidad, muy relacionado con el contexto histórico).

D) Los "principios contradictorios" de la Pragmática. Nos referimos a esos principios que contravienen algunas de las máximas desarrolladas por Grice y nos fijamos concretamente en los principios de la lítotes y de la hipérbole analizados por Ascombre y Ducrot (1983) que recomendaban, respectivamente, decir menos de lo que se puede decir; y explayarse en algunos casos:

O. Ducrot fijaba tres principios pragmáticos que son en sí mismos contradictorios. El principio de economía nos aconseja emplear la palabra justa, no desperdiciar. La ley de litotes, por el contrario, nos aconseja decir menos de lo que se quiere decir. Y, por último, la ley de hipérbole nos pide exagerar, sobrepasar en la expresión los límites de lo verdadero. (...) Hemos de utilizar la litotes cuando hablemos de lo que ganamos, de dinero propio, de nuestros méritos, de nuestros hijos, de enfermedades. .. De esta manera, cuando alguien diga He ahorrado un poco de dinero, el interlocutor tendrá que aplicar un efecto multiplicador. Por el contrario, hemos de aplicar la hipérbole en presentaciones (de amigos, de conferenciantes, de políticos...), en agradecimientos, en declaraciones de amor... (Gutiérrez Ordóñez, 2005: 33)

Consideramos que ambos principios producen multitud de exponentes y ejemplos dentro de los diálogos y de las obras literarias.

E) Principio de adecuación: conlleva adaptación al tema, a la situación o al lugar y/ o a la persona, se ha de acomodar a una finalidad y ajustarse a un tono o nivel de formalidad, no ha de chocar con las normas del grupo social ni vulnerar las creencias personales y, finalmente, se ha de adaptar al nivel de lengua sugerido, a las normas de cortesía y de urbanidad; y entrar dentro del espectro del llamado lenguaje políticamente correcto. Este principio también se relaciona con la coherencia de la comunicación. 
Nos atenemos, como anteriormente hemos defendido, a que diálogo y pragmática son dos esferas altamente interrelacionadas. Pues, el diálogo, descontextualizado, estaría dentro del ámbito de la lingüística que "asume la explicación de los fenómenos codificados al lenguaje (la conformación del significado), mientras que a la pragmática se le asignan los procesos comunicativos inferenciales (la articulación del sentido)" (Gutiérrez Ordóñez, 2015: 16). Por otro lado, no se puede dejar al margen la relación de los enunciados lingüísticos cuyas propiedades externas (carácter comunicativo, ausencia de relaciones sintomáticas y su completud semántica) son proporcionadas gracias a la existencia de la modalidad (asertiva, interrogativa, exclamativa, desiderativa y apelativa) que a su vez guarda una vinculación nuclear con los actos de habla cristalizados en ejemplos como la pregunta, la invitación, el reproche, la petición, la afirmación, etc. (Gutiérrez Ordóñez, 2015). Estos actos eran definidos por Austin (1962) como performativos, es decir, que comunicaban hechos o se consideraban tipos de comunicación particulares de hacers.

Hasta aquí hemos mostrado las relaciones más representativas entre el diálogo y la pragmática.

\subsection{Estructuras del modo dialógico}

Dentro del modo dialógico, en relación con la comunicación real, encontramos diversos exponentes que muchas veces se presentarán en el diálogo de los dramas actuales. Como la revisión que estamos realizando versará sobre obras teatrales actuales tendremos como base de búsqueda una selección de ítems de la Nueva Gramática de la Lengua Española (2011), en adelante NGLE, entre otros motivos que ya hemos explicado en líneas anteriores.

\subsubsection{El verbo: tiempo y aspecto}

Dentro de las formas verbales vinculadas al modo dialógico, lógicamente hemos de referirnos al tiempo presente en primer lugar, por ser el tiempo que designa la coincidencia de la situación mencionada con el momento de habla. Esta coincidencia de situación y momento de habla es muy recurrente en la escritura dramática de los dramas actuales y anteriores por acercar la realidad de la ficción a la realidad del público, de los que escuchan o leen el texto, etc. Este aspecto, como veremos, no significará que en la escritura dramática "no se

${ }^{8}$ Aunque en un principio se dividían en constatativos y performativos -los primeros servían para hacer aseveraciones y los segundos para "llevar a cabo un acto de hacer más que de decir" (Lyons, 1997: 265) - finalmente se dedujo que los constatativos eran un tipo de acto performativo. 
pueda hablar en pasado". Los tiempos verbales pretéritos también se usarán para representar variedad de situaciones como los sueños, los recuerdos, etc. Como acabamos de comentar, y siguiendo las coordenadas de los usos dialógicos, nos figuramos que este uso del tiempo presente no es el único que estará vinculado con nuestra búsqueda9. En primer lugar, el tiempo verbal coincide con los pronombres demostrativos en que es una CATEGORÍA DEÍCTICA: localiza el momento en que suceden los sucesos en relación con el momento en que se habla. Podremos revisar varios tipos y ejemplos como el presente puntual actual o momentáneo, el uso progresivo presente (con formas de estar + gerundio: Te estoy hablando, Estás cambiando mucho, etc. y con oraciones en presente de indicativo que adquieran un valor de duración similar al de la estructura estar + gerundio) relacionado con el presente continuo, actual o extendido el apremio o la obligación de lo que se expresa siempre y cuando hagan referencia a situaciones estáticas. Uno de los usos más extendidos es el de presente histórico o el presente de hechos representados cuya proyección se basa en intentar traer al presente hechos que ya han sucedido y que es propio de los titulares de prensa o de pies de foto (Messi mete el segundo gol). El presente narrativo mezcla formas pretéritas con con el presente para acercarnos la historia que se está narrando de un modo más dinámico (Estaba yo friendo unas croquetas cuando de pronto me llama mi tío Luis para contarme...). También sería importante mencionar el presente de sucesos recientes, el presente prospectivo o el presente de mandato ( Te callas).

Otros tiempos cuya correlación temporal a veces se corresponde con esferas temporales que difieren de su naturaleza temporal típica ${ }^{10}$ son el pretérito perfecto compuesto ya que, como decía Andrés Bello, se trata de un antepresente que se corresponde con la denominación de presente continuo o extendido que hemos comentado más arriba (Ejemplo: Siempre he vivido aquí -> Sigo viviendo aquí). Dentro de este tiempo cabe señalar la interpretación perfectiva de aoristo en la que el pretérito perfecto compuesto sustituye al pretérito perfecto simple en ejemplos como Ha muerto hace dos meses. Por otro lado, tenemos el pretérito perfecto de noticias presentes (que contempla una noticia en un estado imperfectivo cuando en realidad se sitúa en un estado ya terminado como en el ejemplo Un soldado ha resultado

\footnotetext{
${ }^{9}$ Muchos de nuestros ejemplos de usos están sacados directamente de la NGLE.

${ }^{10}$ Sin embargo, no es nuestra intención señalar todas las posibles correlaciones temporales sino las que, bajo nuestro punto de vista, puedan tener un mayor impacto en la competencia pragmática desde el diálogo.
} 
muerto en el bombardeo a la base militar); o el perfecto resultativo (ejemplos como El jarrón se ha roto también significan El jarrón está roto).

En relación al pretérito perfecto simple nos interesa señalar la interpretación anticipativa cercana a un matiz prospectivo. En ejemplos como Allí va el ladrón y la policía detrás... ya lo agarraron, ya lo agarraron... el tiempo pretérito significa "lo van a agarra ahora mismo". Es decir, se refiere a situaciones que no han sucedido pero son inminentes.

Es interesante indicar en el apartado verbal la noción de copretérito cuando nos referimos al tiempo verbal del pretérito imperfecto de indicativo. En este sentido, el tiempo verbal coexiste con otro tiempo dando lugar a ciertos usos modales como el del alejamiento, la evocación o el imperfecto onírico de figuración, relacionado a su vez con la narración y con el uso lúdico (ejemplo: ¿Jugamos a que yo era el oso?) cuya base es la de describir hechos soñados o imaginados, siendo un uso muy recurrente en la creación dramatúrgica por ser un típico recurso de la creación oral de narraciones y cuentos. El imperfecto de cortesía posee una clara relación desde un plano pragmático y su correlación temporal se vincula a un tiempo presente (Ejemplo: Me quería excusar es igual a Me quiero excusar). Con los verbos querer y desear, el imperfecto alterna con el condicional simple. El imperfecto de cita o citativo conlleva un sentido pragmático en toda su extensión pues su idea es la de permitir al hablante que quede eximido, desde un punto de vista de deixis temporal, de la responsabilidad directa de sus palabras por presentarlas como información emitida por otros (Ejemplo: cuando decimos Tú eras de Bilbao, ¿no? es igual que decir que si es cierta la información conocida o escuchada según la cual el receptor es originario de esta ciudad). Por último, el uso modal del imperfecto prospectivo, relacionado con hechos planificados o previstos, constituye un marco o plan de actuación relacionado con la intención del hablante (Ejemplo: En principio, mi avión salía hoy a las 17.00).

Otro tiempo verbal que se conecta al diálogo y a la pragmática es el condicional simple. Su uso de futuro hipotético, con clara proyección prospectiva, tiene un carácter intencional interesante. (Ejemplo: Me gustaría viajar a Sevilla). También el uso de rumor, atenuación o cortesía (Ej.: Convendría salir pronto) están cercanos a una esfera temporal presente (es decir, recogiendo el ejemplo anterior, se correspondería con Conviene salir pronto)

El último tiempo que vamos a incluir en esta lista será el de futuro simple: todos los usos relacionados con las recomendaciones, las advertencias, las predicciones, los mandatos, las conjeturas, las constataciones o verificaciones 
a través de verbos de entendimiento o la perífrasis de ir + infinitivo; forman parte del abanico de relaciones entre el diálogo y la pragmática.

\subsubsection{Otros conceptos dialógicos para un análisis de la competencia pragmática en el texto dramático}

El estilo directo por ser una recreación total de las formas dialógicas ha de ser un concepto reseñable en esta investigación. Comenta Gutiérrez Ordóñez que, a través de los verbos de lengua, que reflejan el puro acto locutivo, se contempla una proporción eficaz entre información contextual e información codificada y ésta suele estar en relación de proporcionalidad inversa. "De ahí que no sean raros mensajes en cuyo segmento $A$ se elide el verbo o el sujeto. La elisión del verbo que es más frecuente que la del verbo se realiza con verbos dicendi (Ej.: Reagan: "Defenderemos a nuestros aliados")" (1986: 28).

La interjección forma grupos de palabras invariables que pronunciadas con tono exclamativo presentan por sí solas estados de ánimo del hablante y suponen actos de habla apelativos. Tanto las de tipo apelativo, relacionadas con las funciones sociales de saludos, despedidas, brindis, etc., cuyo objetivo es provocar en el hablante que realice una acción o tenga una reacción emocional; como las expresivas o sintomáticas relacionadas con la expresión de sentimientos del hablante y cuyo objetivo es manifestar sensaciones o estados de ánimo, son objeto de estudio desde un punto de vista pragmático. Todas ellas están especializadas en la formación de enunciados exclamativos y sirven para la expresión de sentimientos, impresiones, reacciones afectivas que induzcan a la acción, etc. Tienen una importancia fundamental en la legua conversacional pues codifican verbalmente comportamientos sociales y convenciones ya indicadas antes. Se identifican con las voces naturales, constituyendo actos de habla por sí mismas, y por ello tienen un impacto muy acusado en el diálogo real y su uso impulsa a la acción (brindis, rechazo, alegría, etc.) más que a la expresión ${ }^{11}$. Forman enunciados y no modifican las demás palabras a las que acompañan. Es habitual encontrárnoslas concatenadas y duplicadas (¡Vaya, vaya! ¡Bueno, bueno!) con un rasgo iterativo en la comunicación. Dentro de este grupo tendríamos las locuciones interjectivas formadas por más de una palabra ( CCómo no!, jAhí va!) o los grupos interjectivos sintácticos que se acompaña de complementos ( $A$ y de mí!, Caramba con el niño, Cuidado con el perro) que no son piezas léxicas por acompañarse de estas piezas gramaticales y tampoco pueden ser encontradas en el diccionario. Las onomatopeyas, unidades interjectivas, suponen sonidos,

${ }^{11}$ Es decir, no expresan cosas sino que más bien "las hacen". 
a veces reales, de acciones características tanto del mundo físico, como de los animales como propios de las personas (Ring, ring Bang, bang, Achús, Jeje, Croac, Miau, etc.). La interjección da lugar a enunciados exclamativos como los que se dan en ;Cuánto esfuerzo!, ¡Magnífico partido!, de tipo nominal; en Demasiado bueno, Muy correcto, de tipo adjetival; en ¡No tan rápido!, ¡Qué cerca!, de tipo adverbial; en jSaliendo!, jBien hecho!, de tipo verbal. En otro lugar se encuentran las oraciones exclamativas totales y parciales; se diferencian porque las segundas se construyen con elementos sintácticos para poder ser realizadas ( Cuántas oportunidades hemos perdido!), las primeras se diferencian de las declarativas por su entonación (jEstoy agotado!). Las expresiones vocativas también se relacionan con las interjecciones por suponer actos de habla exclamativos referidos a una segunda persona ( $i E h$, túl; Venga aquí, caballero; iEstate quieta, niñal). Estas expresiones suelen acompañarse de interjecciones puras (Ey, Máster, ven aquí). Algunas características que hacen singulares a este contenido de la lengua son los aspectos fonéticos que las hacen mutar incluso cuando se trata de la misma interjección. Por ejemplo, la interjección hala con pronunciación llana supone llamada a la acción y con aguda supone sorpresa, al igual que ocurre con jope y jopé. Muchas de las interjecciones tienen tendencia al monosilabismo como le ocurre a las onomatopeyas (brum, clic, glu, plof, tac, etc.). En el discurso directo, es muy fácil encontrarnos interjecciones acompañadas de verbos de lengua: Mi madre suspiró: "Oh, Dios mío!". Muchas interjecciones se crean a partir de sustantivos (Caracoles, Cielos, Rayos) y en relación con la modalidad son abundantes las interjecciones creadas a partir de un imperativo que sufrieron un proceso de lexicalización (arrea, atiza, sopla, venga, mira, calla, oye, etc.) o los adverbios lexicalizados reconvertidos en interjección (jArriba los amigos!, ¡Adelante el amor!). Muchos eufemismos son en realidad interjecciones que contienen un par informal pero no coloquial o vulgar (concho/ coño; no fastidies/ no jodas; jo/ joder; me cachis/ me cago; cago en diez/ cago en dios; ostras/ ostias, etc.).

Como hemos dicho antes, existe la clasificación entre interjecciones apelativas y expresivas. Comentaremos algunas de ellas muy relacionadas con el diálogo desde un punto de vista pragmático. Las primeras se orientan hacia el oyente y las segundas hacia el hablante. A veces, según el contexto, pueden intercambiar un uso apelativo y un uso expresivo. La modulación tonal en muchos caos será la que determine el tipo de uso como puede pasar en anda, hala, hombre o venga. Entre las apelativas destacan varios usos: las de saludo y despedida (hola, adiós, salud, abur o agur, epa, choy, chao), las expresiones 
acuñadas de saludo o despedida (cuánto bueno, dichosos los ojos, qué hay, con Dios) o las locuciones típicas con hasta (hasta ahora, hasta luego, hasta otro, hasta más ver o la informal hastalué). Dentro de las apelativas, los saludos por teléfono variarán según el lugar de procedencia desde el que se hable castellano (Diga en España, Hola, Qué hay, Aló, Bueno en Hispanoamérica). Otras interjecciones apelativas son las que se refieren a distintos actos de habla como estornudar, los brindis, el acto de comer, el agradecimiento y su respuesta, etc. (Salud, Jesús, chinchín, Que aproveche, Mil gracias, Infinitas gracias, A mandar, No faltaba más, No las merece, etc.). Los actos de habla como la promesa, las advertencias, dar ánimos, pedir silencio, fórmulas de los mandos militares, para expresarse con animales, etc. son muy comunes en la lengua conversacional (Palabra, Palabra de honor, Palabrita del niño Jesús, jEh!, jAlto!, Adelante, Anmo, Arriba, Epa, Sh, Chitón, Ar, Fir, Zape, Arre, Tus Tus, etc.). Las expresivas, por otro lado, pondrán en escena diferentes estados de ánimo. Encontraremos las que manifiestan contrariedad como carajo, demonios, lástima, leche(s), mierda, puñetas, etc. y locuciones expresivas o imperativos con este mismo uso ( $Y$ dale con la música!, Arrea, Toma, Atiza, Vaya). Otras, ya mencionadas anteriormente, expresan perplejidad (ostras, caramba, corcho, tate pero cómo, etc.) y varias que sirven para llamar la atención y tienen un contexto religioso (Vaya con el niño, ahí va, cómo va a ser, mira tú o mirá vos, mira por dónde, Ay madre, Ay Dios, Jesús María y José, etc.). Muchas de éstas se forman a través de imperativos negativos (No me digas, No fastidies o la vulgar ya utilizada $N o$-me- jodas, No te jode). Son muy usuales las que expresan admiración o aplauso (bravo, chapó, guau, olé, ole). Otras interjecciones se relacionarán con el entusiasmo (Viva, Vamos), el asco (Puaj, $U g h$ ), el énfasis de los juramentos (Por éstas, Como me llamo__ ), el dolor físico y de alma $(j A y 1)$, la percepción de las cosas $(A h)$, la aprobación (Desde luego, Cómo no), la confirmación o la conformidad (Dale, Venga), la resignación (Bueno), la indiferencia o el desdén (Bah, Pchê), la negación u oposición (Anda ya, Qué dices) o el final de una acción (Sanseacabó, Finito). Por último, podemos mencionar algunos ejemplos de grupos interjectivos que se asocian a complementos u oraciones ( $j \mathrm{Oh}$, cielos!, jAy de mí!, etc.) y el gran abanico de expresiones que se forman con las interjecciones Ojalá, Así, Vaya (Ojalá le vaya bien, Así se entere de lo que es bueno, Vaya que sí llegó el amigo de la novia, etc.).

También es importante mencionar la importancia de las perífrasis modales así como las tempoaspectuales, las de gerundio y participio así como 
el imperativo, las distintas formas de modalidad en enunciados exhortativos y desiderativos y algunos aspectos de la interrogación y de la exclamación ${ }^{12}$.

\section{Conceptos de la pragmática dialógica en muestras teatrales}

En este epígrafe vamos a rastrear algunos ejemplos de una pequeña selección de obras teatrales contemporáneas escritas en lengua española y el uso de los exponentes lingüísticos que hemos comentado en el apartado anterior. También comentaremos algunas líneas del argumento de las obras seleccionada cuando éste tenga una influencia en la comunicación dialógica que afecte al desarrollo de la competencia pragmática.

\subsection{El tiempo que estemos juntos de Pablo Messiez}

En primer lugar, elegiremos la obra del dramaturgo bonaerense Pablo Messiez (1974) llamada El tiempo que estemos juntos (2019). El argumento de la obra comienza con una joven pareja visitando un piso para convertirse en sus nuevos inquilinos. Les encanta el piso y deciden ser alquilados por su casera. Sin embargo, parece que dentro de ese piso conviven otros personajes invisibles -aunque sí sentidos- para la joven pareja. Todos ellos, llamados Los inconsolables, hablarán del amor, la soledad, y la fragilidad humana buscando un alivio a lo absurdo del mundo, haciendo rituales cuyas normas solo ellos conocen, cantando para mitigar la desesperación, llenando el espacio de sus propias historias, de su pasado, etc. Dice Messiez de ellos en la primera acotación (2019: 19): "No están ahí. Aunque han estado ahí hace justo cinco años”. De forma paralela, la joven pareja vivirá una crisis existencial y de pareja cuya mecha parece haber sido encendida por esas presencias que si no reales producen un efecto real en los inquilinos. Continúa en la primera acotación el autor diciendo: "Como en un pliegue del tiempo, vemos a la vez lo que sucedió entonces y lo que está pasando ahora. El espacio es uno. Los tiempos $\operatorname{dos}(\ldots)$.

La obra empieza con la casera entrando en la casa, con un pañuelo en la cabeza y con mal aspecto, con ojeras, palidez y expresión triste -así se nos cuenta en la primera acotación-. Empieza a arreglar un poco la casa y espera

\footnotetext{
${ }^{12}$ La explicación de las perífrasis y estos ítems mencionados daría incluso para otro estudio pero por cuestiones de tiempo y espacio, dejaremos su explicación gramatical y pragmática para futuros trabajos. En la parte de análisis de muestras teatrales sí que mencionaremos algunos de estos conceptos por considerarlos importantes desde la perspectiva pragmático- dialógica.
} 
a la joven pareja que parece que llegan tarde. Júlia, la casera, toma el teléfono e inaugura el diálogo con la siguiente frase:

Júlia- ¿Hola, Claudia? Habíamos quedado a las 12 h, ¿no? (Pausa) Ya, si era por chequear nomás. Ah, perfecto, perfecto, perfecto. Hasta ahora.

Todo comienzo puede ser prometedor: en las primeras palabras de muchas de las obras teatrales se clarifican las líneas generales de conflicto, relaciones entre personajes, etc. que pueden existir en el desarrollo de la historia. A veces, con las primeras líneas, podemos intuir gran parte del argumento de la historia que comprendemos después de haberla visto o leído, a posteriori. Creemos que es el caso de esta pieza teatral. Solo en estas dos primeras frases se esconden varios conceptos de pragmática dialógica y de vínculos cuya base conflictiva se desprende a lo largo del argumento. En primer lugar, observamos ese tiempo de pretérito pluscuamperfecto de indicativo que, como indica Gutiérrez Araus (2014) citando a Andrés Bello, supone el punto de referencia de la temporalidad marcado, que ha decidido el enunciador, en este caso Júlia, determinando cómo se establecen las relaciones temporales y, añadimos, las relaciones de subordinación entre los distintos personajes. La casera, Júlia, decide que va a estar al mando en la relación jerárquica comunicativa de este grupo. Ella se adelanta a la pareja y es la que impone la norma de recibir la autoridad de ser quien les pida o reclame algo a los futuros inquilinos Claudia y Edu, en lugar de ser la pareja la que pueda reclamar si el piso tiene buenas condiciones o no, como plantea el marco de la situación comunicativa casero que muestra piso- clientes que evalúan el piso. Al Júlia afearles a la pareja, de manera cortés, la conducta de haber llegado tarde, les arrebata el poder de ser ellos los "dueños" de la conversación. Júlia, está haciendo uso de esta ancla temporal para deslizar un pequeño reproche por la falta de decoro de la joven pareja. Al expresar la anterioridad de un acuerdo tácito que habían refrendado tanto casero como la pareja de inquilinos de verse en una fecha, lugar y hora determinadas, el tiempo verbal acoge un rasgo que va más allá del uso característico de mostrar una acción del pasado previa a otra situación pasada. Se refuerza esta llamada de atención con el adverbio de negación no en forma de pregunta con sentido retórico que en este caso adquiere una naturaleza interjectiva. Este pequeño reproche lo va a atemperar la casera en la siguiente frase de modo veloz intentando crear en el oyente, Claudia y Edu (suponemos que los dos inquilinos, aunque sea Claudia la que está al teléfono, están escuchando la conversación con la salvedad de que a Edu le falta escuchar las palabras de Júlia pero, como suele suceder en este tipo de conversaciones telefónicas, 
las supone por el contexto), un bálsamo de "tranquilidad comunicativa". Veamos cómo: con claridad, la casera usa varias unidades dialógicas para reducir el efecto jerárquico de la primera frase que son

A) El uso de la interjección $Y a$ con tono coloquial y que indica solidaridad con el oyente.

B) El uso de la apódosis más el pretérito imperfecto junto a la preposición por. Este grupo sintáctico tiene el objeto de volver al principio de cortesía defendido por Grice. Es posible que Júlia se haya sentido brusca ante la respuesta de Claudia, su tono, la forma de disculparse, etc.

C) Uso del adverbio compuesto nomás. Este adverbio tiene una frecuencia de uso mucho mayor en Latinoamérica comparándolo con España. Messiez es argentino y tal vez haya jugado con el efecto que este adverbio puede tener en la recepción de los castellanohablantes peninsulares ${ }^{13}$, dando un matiz de mayor suavidad que sus correspondientes expresiones adverbiales más comunes en España nada más, apenas.

D) El uso de la interjección $A h$ de percepción más el adjetivo interjectivo perfecto triplicado, acusando más su actitud de bálsamo para volver al tablero de la cortesía.

Justificamos esta actitud a la que nos hemos referido antes de reproche de Júlia, cuando se produce el encuentro entre casera y pareja viendo, a través de las palabras, pues su actitud es lacónica, más bien tacaña, hacia la alegría y vitalidad de la pareja ${ }^{14}$, rebosantes de ilusión y de ganas de "comerse el mundo" al, por fin -dice Edu después de que decidan quedarse con el piso "iiiSí!!! ¡Por fin! Ventidós pisos hemos visto."-, encontrar la casa en la que desean vivir. Messiez escribe (2019: 20) ante el primer encuentro de la casera y la pareja: "Todos se saludan y es notable el contraste de ánimo de los enamorados y del de Júlia que disimula mal su pena".

El diálogo continúa con las palabras tristes de Júlia:

Júlia - Pues esto es.

Claudia - ¡Mira la luz, mira la luz, mira la luz! (Pausa) Está bien ¿no?

\footnotetext{
13 Recordemos que la obra El tiempo que estemos juntos fue un encargo para ser estrenada en España, más concretamente en el Teatro Lliure de Barcelona. El autor lo cuenta en el prólogo de la obra (2019: 9): “El tiempo que estemos juntos nace de la invitación que me hiciera en 2017 Lluís Pascual (en ese momento director del Teatro Lliure) a escribir y dirigir un montaje para la Kompanya Lliure (conformada por cuatro actrices y cuatro actores jóvenes)".

${ }^{14}$ Incluso, más adelante, cuando la pareja dé el paso de quedarse con la casa, Júlia les espetará:

“(Extrañada) ¿Estáis como muy contentos, no?”
} 
Sigue el contraste de actitudes reflejado en el sobrio uso del pronombre demostrativo de género neutro de Júlia y la concatenación del mismo imperativo (tres veces) de Claudia hacia su novio e incluso hacia la casera pues la muestra pública de su actitud puede suponer también una llamada de atención a la casera por no corresponderse, aunque sea de manera tibia, con la actitud de los jóvenes. Además, es importante recalcar que en la designación de los personajes Júlia aparece como uno de los personajes de los inconsolables, de esos personajes tristes que no tienen consuelo y que no son vistos por los nuevos inquilinos. Júlia puede ser el personaje con mayor entidad de ellos pues en el comienzo sí que es vista y percibida como una persona real. Queremos entender que, aunque no podamos escuchar el texto, la diferencia en el uso de elementos suprasegmentales es notable, tanto en la entonación, el ritmo, las pausas, los acentos, etc. como en los gestos, entre la casera y la pareja. Júlia les responde a sus preguntas sobre el piso con monosílabos "El baño. Aquí. Y la cocina Aquí, pareciera que no quiere alquilarles el piso y que no solo no se corresponde con la actitud de la pareja sino que la detesta. Está infringiendo de nuevo varias normas de Grice (supresión abierta, conflicto e incluso desprecio de las normas) y contraviniéndolos a través de los principios contradictorios de litotes diciendo menos de lo que se puede decir. Hay en Júlia cierta actitud de que no quiere que vivan allí $\mathrm{y}$, por supuesto, adquirimos la lucidez de este planteamiento cuando observamos que la casa ya está ocupada por esos personajes, los inconsolables, que no son vistos ni oídos en un principio, como si fueran fantasmas. El uso de la anáfora, por otro lado, va a ser muy común para el personaje de Júlia: no quiere repetir nada que no haga falta. Cuando los novios ya están decidiendo que esa va a ser su casa, Claudia le pregunta a su futura casera si el piano que hay en la casa se queda. La respuesta de Júlia no tiene desperdicio desde un punto de vista pragmático: "Todo se queda". El principio o norma de economía o cantidad está chocando con el de manera. ¿Qué significa que todo se queda? ¿También las presencias de los inconsolables que nadie, al parecer ${ }^{15}$, puede percibir? El principio de cortesía, además, hubiera preferido una respuesta del tipo "Sí, es un piano con un valor económico y sentimental muy grande, es de 1940...", "Sí, la verdad es que es uno de los objetos de la casa del que no nos queremos deshacer", etc. Esta actitud que vamos comentando en la casera se comprueba de manera fehaciente cuando el novio, Edu, le pregunta si el patio es todo eso

15 Y decimos al parecer pues Claudia captará más adelante los sonidos de estos personajes e incluso verá a uno de ellos asuntándose y percatándose de que su novio Edu no puede ver ni oír nada. 
que ve. Júlia afirma: "Sí, todo. (para sí) No, si va a ser medio patio, idiota...". El insulto, aunque sea para sí misma, es percibido tanto por el lector como por el espectador. Con ello, la norma de cortesía se ve perjudicada y la intención de la casera queda patente al declarar la falta de inteligencia, alimentada por el entusiasmo, del novio. Los novios quieren quedarse la casa y Júlia les comenta, dos veces, si quieren más tiempo para pensárselo.

Avancemos un poco en la trama: los novios han decidido instalarse en la casa y la pareja ya empieza a hacer planes en relación a la casa. Mientras tanto, los inconsolables aparecen en escena: vuelve Júlia a la casa, suponemos que de su encuentro con la pareja, con mucho mejor aspecto pero vuelve a una dimensión en la que la pareja, que ahora mismo está ordenando cosas por la casa en esos momentos, no les captan. Veamos algunas líneas de este momento del diálogo en el que Ros, uno de los inconsolables, confronta a Júlia:

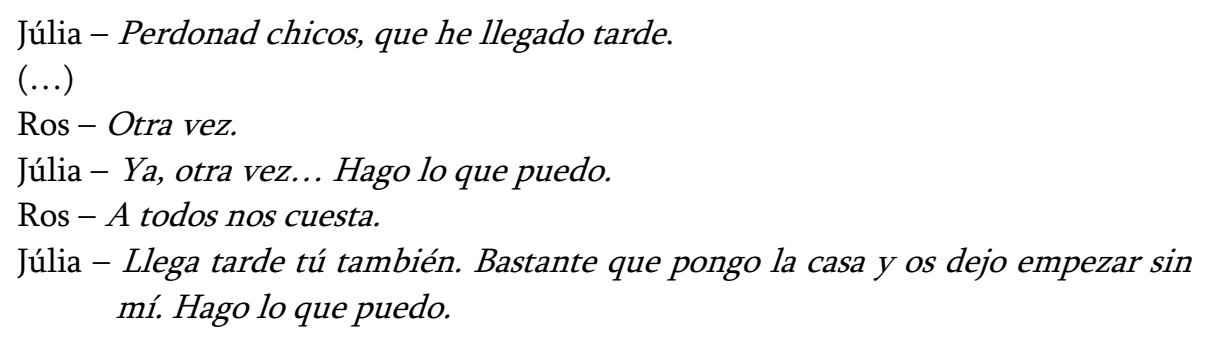

Se mantiene la modalidad de cantidad entre personajes que, desde otro prisma distinto al que analizamos entre la casera y la pareja, se tratan de igual a igual. La misma máxima de cantidad, sin embargo, afecta a la máxima de manera pues, hay cierta oscuridad en la expresión con apenas seis o siete palabras. También hay un reproche velado de Ros que se corta rápidamente imponiendo, nuevamente, Júlia su jerarquía sobre el grupo de los inconsolables con la última línea del diálogo que hemos marcado. Júlia ha de imponer su liderazgo tanto en esta dimensión "espiritual" como en la real donde, en momentos posteriores, están Claudia y Edu, la joven pareja, decidiendo cambios sobre la casa. Veamos la primera parte del diálogo:

Los inconsolables empiezan a mirar de otro modo como si fueran niños. (...) Nadie habla.

Claudia - Tenemos que cambiar los muebles... Y el color de la pared...

Edu - Bueno, poco a poco, amor... Tenemos tiempo.

Hay varios aspectos reseñables en estas primeras líneas desde un punto de vista pragmático. En primer lugar, la acotación "como si fueran niños" nos hace suponer un punto de comienzo, tanto en los inconsolables como en la pareja. Esta comparación hipotética con el imperfecto de subjuntivo nos 
lleva a un punto de partida tanto para los personajes "invisibles" como para la pareja de Claudia y Edu. El diálogo comienza con un acto de habla directivo a través de la perífrasis modal Tener que + imperativo. Claudia le está exigiendo a Edu cambios, primero serán en la casa, después, cuando vayamos avanzando en la historia, serán en su relación. Edu, a cambio, y a través de la interjección Bueno expresa resignación y disconformidad (ambas actitudes serán un leitmotiv en la actitud del novio durante la obra) reforzadas con la locución adverbial poco a poco. Los dos novios usan el verbo tener en primera persona del plural, ella para pedir cambios, él para pedir tiempo. El acto directivo de Claudia choca con el acto compromisivo de Edu, un acto enmascardamente compromisivo pues, entendemos cuando va avanzando la trama, que él no quiere o no puede cambiar en la línea que le pide Claudia y que el tiempo que dice que tienen, tanto para la casa como para la pareja, es un tiempo para agotar las demandas de su novia. Ella, que parece intuir esta intención encubierta en su novio, le responde:

Claudia - Ya, pero en cuanto podamos tenemos que hacerlo, que es importante que estemos a gusto en nuestra casa.

Claudia no se rinde a pesar de usar la interjección Ya denotando que hace caso o que recuerda un pacto tácito anterior. Vuelve, a través de la misma perífrasis modal, a reforzar su acto de habla directivo reforzado con la oración impersonal ser + adjetivo + que + subjuntivo que potencia el acto a través de la valoración y de la necesidad de estar a gusto que se desprende de la frase. Con estos actos directivos, Claudia también está reforzando el contexto físico llamando a su novio a realizar cambios manuales en la casa (cambiar muebles, el color de la pared, etc.). Edu le pregunta con encomio si no está a gusto en la casa o no le gusta. Claudia responde afirmativamente y Edu comenta lo siguiente:

Edu - ¿Cómo era eso que me decías cuando me llevabas a un lugar que no me gustaba? Lo de "el lugar va con uno..."

Claudia - "El lugar lo hace uno"

En primer lugar, Edu usa el imperfecto de cita o citativo junto al adverbio interrogativo de manera Cómo que modifica el grupo verbal e introduce un acto de habla directo a través de la oración interrogativa directa. Aquí, el imperfecto de cita está conminando a Claudia a que recuerde algo que ella declaró sobre los lugares. Como sabemos, el imperfecto de cita recoge la pregunta de un acto perfectivo (alguien dijo en el pasado esa información) para ofrecerla de nuevo en un marco imperfectivo (el presente). Después Claudia responde al acto 
directivo de su novio con un presente de indicativo gnómico relacionado con los dichos o proverbios que alcanza su influencia tanto en las áreas del pasado y del presente como en las del futuro (El lugar lo hace uno siempre: ayer, hoy y mañana).

Terminamos con un último ejemplo de esta obra. Ha pasado el tiempo en la obra y la pareja empieza a resentirse por vivir en esa casa, Claudia desde un punto de vista activo (pues puede escuchar las voces y los ruidos de los inconsolables, más adelante incluso se comunicará con una de ellas) y Edu desde un punto de vista pasivo (él no percibe nada y eso desgasta la relación con su pareja al no comprender qué está viendo u oyendo Claudia y crear la sospecha de que no está del todo cuerda). Claudia comienza a hablar:

Claudia - (Mirando a Edu) Todo este tiempo, todo este tiempo, todo este tiempo. ¿Cómo saber que has visto? ¿Con quién has estado?

Edu - (Extrañado) Contigo.

Claudia- Ya. Pero, ¿cómo? ¿Con quién? ¿Quién, cómo soy? ¿Seré? ¿Para ti? ¿En tus ojos?

Edu - Hermosa.

Claudia - No digas gilipolleces, Edu. Te estoy hablando en serio.

Edu - Yo también. En serio, eres hermosa. Mi idea de la hermosura eras tú.

Claudia - ¿Era?

Edu - Eres. Tú.

Este pequeño diálogo está asociado a varias relaciones pragmáticas. En primer lugar, Claudia repite tres veces la expresión Todo este tiempo. En varias entrevistas y escritos del autor de la obra, Messiez comenta la idea de "la resonancia" de lo que se dice, de las palabras. Comenta Messiez sobre la resonancia de las palabras (2019: pp. 136-138):

Saber cuáles son. Cómo suenan. Conocer las pequeñas acciones que posibilitan la acción global y dejar que el sentido aparezca como repercusión de la relación entre las partes. (...) Darle espacio a la resonancia de las palabras (...). No pretender saber de antemano más que las palabras y que sean ellas las que informan al cuerpo (...). Encarnar es convertir la palabra en declaración. Dejarla resonar en el cuerpo. Mezclarla con el cuerpo hasta volverla materia. Dejar que dialogue con la propia historia, para poder decirla. Dedicarla en la exhalación y dejarse mover completamente.

Creemos que en esta triple repetición se encuentra totalmente la idea de la resonancia defendida por el autor. Claudia está intentando crear el tiempo, palparlo, hacerlo tangible. Le pregunta a sus ojos, a ella misma y a su pareja. Son 
dos preguntas que suponen un acto de habla directo. Y esta idea se refuerza con otras palabras del autor (2019: 143) sobre la idea de la resonancia: "La dirección de la repercusión es doble: mueve a quien escucha pero también a quien ha hablado, transformado ya por haber dicho". En este caso, comprobamos esta transformación doble. Claudia se dirige a la lucidez y Edu al extrañamiento. Claudia no está intentando dar información en clave aunque a Edu sí le parezca que hay algo oculto en sus palabras. Claudia está en un lugar lejano al que se encuentra Edu (más adelante, cuando la pareja esté casi rota, Edu le dirá a Claudia "Ya me he ido. Nos hemos ido los dos hace tiempo. Están los cuerpos, nuestros cuerpos. Y la casa. Y las cosas. Pero ya todo se sabe ausencia”.); y él no comprende nada. El uso del pretérito perfecto en ambas preguntas recoge completamente la noción de Antepresente defendida por Bello. El tiempo se extiende desde el pasado y es patente en nuestro presente. Claudia le está intentando mostrar a Edu todo el recorrido que ella ha vivido durante este tiempo en la casa, más allá de la forma real de contar nuestro tiempo natural. También podría estar relacionado este uso con la interpretación perfectiva de aoristo: Claudia parece que ya se encuentra más, con relación a lo que siente por su pareja, en una perspectiva inactual pues parece no estar en coincidencia con el momento de la enunciación por ese matiz de lejanía que hemos comentado.

Claudia, de nuevo, intenta acercar a Edu al lugar "espiritual" en el que se encuentra con varias preguntas directas que suponen actos de habla directivos. En total siete preguntas que desbordan la comprensión en una posible respuesta por parte del novio. La concatenación de preguntas exigen cierta urgencia en la respuesta de Edu: Claudia le está pidiendo respuestas, clarividencia ante la situación vital que está viviendo. La idea de la resonancia vuelve a ponerla en práctica Claudia. Con ello Claudia está contraviniendo la máxima de manera al expresare de una forma oscura o, como mínimo, ambigua. Edu solo es capaz de responder, en ambas ocasiones, con una palabra (Contigo; Hermosa). Edu, ante la urgencia de Claudia, impone la pausa a través de una sola palabra en cada ocasión de este diálogo. Ante estas respuestas Claudia responde con un imperativo que sí solicita cambios en el destinatario y que se refuerza por el uso de la palabra malsonante gilipolleces. Es decir, que pare de decir tonterías, que vaya al lugar, metafóricamente, donde está la conversación. Claudia sale del letargo en el que parecía encontrarse a través del pretérito perfecto como antepresente y las oraciones interrogativas directas para entrar de lleno en el momento existente a través de la modalidad con el imperativo. Esta respuesta no solo se introduce completamente en la perspectiva actual sino que intenta "bajar" al nivel cognitivo de la conversación en la que se encuentra Edu. 
Es un toque de atención, es una llamada a que siga el ritmo de Claudia. Este uso con el imperativo se fortalece con la perífrasis de estar + gerundio con sentido extendido y que encadena el acto de habla directivo anterior con uno expresivo (equivaldría a "No me estás tomando en serio"). Acto seguido Edu confronta con ella desde la amabilidad. Él le está hablando en serio también. Sin embargo, y tal vez eligiendo adrede un nuevo marco enunciador en forma de ataque, usa el pretérito imperfecto, perspectiva inactual, para decir que la idea de la hermosura era su novia. Edu se defiende de la acusación de ausencia que ha vertido su novia contra ella usando esta forma pretérita. La perspectiva discursiva juega un papel crucial. La cortesía, por otro lado, se ve afectada y la máxima de economía también (tal vez no hacía falta decir la última frase de Edu). Claudia repite la forma verbal en forma de oración interrogativa tanto directa como indirecta (directa: ¿Has dicho "era”?; Indirecta: ¿Se ha acabado nuestro amor, ya no te parezco hermosa?). Supone un acto de habla tanto directo como indirecto. Y Edu, retractándose del ataque, vuelve al presente con solo una frase: Eres. Eres, como acto de habla que alcanza tanto una esfera prospectiva como retrospectiva cuyo peso toma fuerza al añadir otra frase monosílaba, con forma de vocativo: Tú.

Por último, comentaremos que todas las muestras que hemos escogido de esta obra están repletas de implicaturas. En varias ocasiones, los emisores expresan mensajes cuya manifestación no es expresada de manera explícita. Las palabras y los mensajes violan normas que ya hemos analizado, se presuponen y se dejan de presuponer ideas, etc.

\subsection{Burundanga de Jordi Galcerán}

En segundo lugar, seleccionamos el texto del autor catalán Jordi Galcerán (2011). Cuenta en clave de comedia la historia de Berta y sus compañera de piso Sílvia. Berta se ha quedado embarazada de su novio Manel sin que éste lo sepa. Berta tiene miedo de que él no acepte que está embarazada y por ello idea un plan con Sílvia, su compañera de piso y farmacéutica: suministrarle una dosis de la droga burundanga (conocida en los medios de comunicación como "la droga de la verdad") para comprobar si Manel va a comprometerse en la crianza del hijo que viene. Cuando le hacen beber esta droga a Manel sin que él lo sepa, todo se descontrola. Manel, bajo los efectos de la Burundanga, les confiesa a las chicas que pertenece a la banda terrorista de ETA y que un compañero suyo llamado Gorka, que viene del País Vasco y que se dirige a su piso para llevar a cabo una operación en Madrid, también pertenece a la banda. Ambos, Gorka y Manel, idean un secuestro de un importante 
empresario y lo llevan al piso. El empresario, casualmente, es el tío de Silvia, lo que da lugar a situaciones inesperadas.

$\mathrm{Al}$ igual que con El tiempo que estemos juntos, comenzaremos analizando varias líneas del comienzo de la obra. Berta y Silvia están, in media res, planeando suministrarle a Manel la dosis de Burundanga. Veamos sus líneas:

(...)

Berta - ¿Y si le duele?

Sílvia - Qué le va a doler... Esto no tiene ningún efecto secundario. Ninguna contraindicación. Es más inocuo que el agua.

Berta - ¿Seguro?

Sílvia - Vamos a ver... Si le das la dosis que te he preparado no le puede pasar nada. Si le dieras dos litros, a lo mejor sí... Pero si te tomaras dos litros de aceite también te sentarían fatal. En esta vida todo depende de la dosis.

Berta - No sé... No lo tengo claro.

(...)

Sílvia - Querías una solución. Aquí la tienes. Estás preñada. Preñada de un tipo del que, en el fondo, no te fías. Quieres saber lo que tiene dentro de la cabeza. Ésta es la manera.

Berta, como novia, se preocupa por su novio Manel: sus palabras se ajustan a través de dos vértices, manifiestan un acto de habla expresivo y a la vez directivo. Hay preocupación pero también una petición a su compañera farmacéutica de echarse atrás en el plan de drogar a su pareja. A través de la prótasis de la oración condicional real incompleta, debido a que se ha construido a través de una oración interrogativa directa, Sílvia no le está pidiendo explícitamente a Berta que complete la oración condicional con la apódosis pendiente, sino que le está pidiendo piedad o que al menos reconsidere llevar a cabo este plan. Berta, tal y como ocurre con las oraciones condicionales, no está afirmando ni declarando nada. Más bien está expresando un efecto hipotético con alta probabilidad de daño - por eso el uso de la oración condicional real y no de aquellas de menor probabilidad como son la posible "Si le doliera" o la irreal "Si le hubiera dolido" - que, aunque no lo dice explícitamente, conduciría a un resultado de gravedad para la salud de Manel. La respuesta de Sílvia corta toda intención anterior de su compañera usando el pronombre qué de forma exclamativa a través de la interpretación partitiva encubierta o discriminativa en la que se recrimina, como si lo anterior hubiera sido un absurdo, lo que se acaba de decir. Pero parémonos un momento a analizar el resto de la frase de Berta: Esto no tiene ningún efecto secundario. Ninguna contraindicación. Es más inocuo que el agua. Sabemos que Sílvia es farmacéutica y también sabemos, después de una búsqueda sencilla sobre 
los efectos de la droga burundanga por Internet ${ }^{16}$, que Berta miente. Es una mentira que no es piadosa en absoluto sino bastante perniciosa. Existe el juramento hipocrático del farmacéutico (2014) - aunque cada vez surgen nuevas versiones - en el que se dice:

Como farmacéutico, me comprometo a servir a la humanidad y a apoyar los ideales y compromisos de mi profesión. Me guiaré en todas las dimensiones de mi vida por los más altos estándares de conducta humana. Aplicaré todos mis conocimientos y habilidades para favorecer la salud y el bienestar de todos aquellos a quienes sirvo.

Podemos sospechar que Sílvia está faltando al juramento, tal vez, de forma consciente. Las tres frases que hemos adjuntado chocan con la máxima de cualidad llegando casi a violarla a través de las declaraciones y comportamiento de Sílvia. Veremos más adelante en la obra como la toma de la dosis le producirá a Manel un efecto bastante mayor del que decía la farmacéutica. Cuando vuelve Manel de la calle, Sílvia le pide que se beba la cerveza, bebida en la que han puesto la droga las compañeras de piso, de un tirón. Contrastará esta actitud con la de Berta que, antes de que Sílvia aparezca cuando ya llegó Manel, tiene una conversación con su novio ofreciéndole la cerveza pero a la vez aconsejándole que no debería bebérsela. Berta justificará todos su actos de habla en un comportamiento de acción correspondiente a su estado expresivo de lengua y de ánimo.

Por otro lado, la mentira de Sílvia cuando explica los posibles efectos adversos de la droga es un poco más nociva al mezclar falso testimonio con una verdad (Es más inocuo que el agua). De esta manera, dando datos falsos primero pero cerrando con un dato real la frase, Sílvia se puede sentir más segura en su declaración, tal y como sucede en los actos de habla trufados de mentiras pero finalizados con una verdad (como podemos comprobar en algunos discursos de índole sociopolítica). Además, ella refuerza la seguridad de su argumento en su tercera frase (Ninguna contradicción) omitiendo el verbo tener: aunque ya lo dijo en la segunda frase y no tienen necesidad de volver a repetir el verbo, esta ausencia potencia la máxima de economía produciendo el efecto

16 Encontramos por ejemplo un enlace en el que se nos indica: "Una intoxicación con burundanga produce sequedad de piel y mucosas, sed, dificultad para deglutir y hablar, pupilas dilatadas con reacción lenta a la luz y visión borrosa para objetos cercanos. La piel se enrojece por vasodilatación cutánea y disminución de la sudoración e hipertermia marcada". Tomado de: $<$ https://www.infobae.com/2016/04/29/1807670-asi-actua-la-burundanga-el-

organismo/\#: : :text=Efectos\%20t\%C3\%B3xicos,la\%20sudoraci\%C3\%B3n\%20e\%20hipertermia\%20 marcada.> [Consulta realizada el 19- 7-20]. 
comentado de darle a su argumentación un mayor impacto. Berta pregunta de forma directa, también con la omisión del verbo, recayendo en esta máxima de economía usando solo el adjetivo seguro. Este adjetivo ha tomado ciertas características de las unidades de interjección y supone la manifestación tanto de un acto de habla directivo (sacar de dudas a Berta en el riesgo de la droga) como expresivo (exteriorizar su miedo a que todo vaya mal). Después de las dudas de Berta sobre si es segura la droga y no le va a producir ningún efecto secundario, Sílvia responde con el uso de la perífrasis que se ha impuesto desde un punto de vista sociolingüístico: Vamos a ver... En este caso la perífrasis ha perdido todo uso de posterioridad, inminencia, etc. para convertirse en un grupo interjectivo lexicalizado cuyo significado cercano puede ser el de introducción a una pregunta, una orden, queja o explicación, etc., que requiere la atención o la necesidad de confrontar algo con orden.

Esta necesidad de orden también le da a Sílvia cierto tiempo para organizar sus pensamientos antes de responder con otras premisas a la desconfianza de su compañera de piso. Sílvia entonces responde con tres oraciones condicionales: primero una real o de probabilidad alta y después con dos oraciones de probabilidad baja (vemos, por ejemplo, en la segunda oración condicional el apoyo de la baja probabilidad con el uso de la locución adverbial de tipo coloquial a lo mejor cuyo significado cercano es el de duda denotando la posibilidad de que ocurra algo). La concatenación de tres oraciones condicionales, aportando ejemplos reales y posibles del uso de la droga según la dosis, muestran causas y efectos a través de sus correspondientes prótasis y apódosis. Y le sirven a Sílvia, la farmacéutica, para rebajar el largo crédito de falso testimonio que dio en la frase anterior cuando le preguntó Berta sobre el posible daño de la droga en su novio. Ahora sí, Sílvia está ofreciendo actos de habla asertivos con una base real, respetando la máxima de cualidad que fue más o menos violada en su anterior intervención. Digamos que Sílvia en esta ocasión se explaya dando datos, esta vez sí, de mayor certeza. Aunque, recordemos, hay susceptibilidad de poder pensar que todo esto será papel mojado a posteriori por su forma de reaccionar cuando le den la droga a Manel. Sílvia comenta que, lógicamente, con una dosis de dos litros a Manel sí le pasaría algo, como si alguien tomara dos litros de aceite. Y cierra su declaración con una frase en forma de dicho que refuerza los argumentos ofrecidos con relación a la droga y sirve como conclusión y punto final de defensa al acto delictivo que van a cometer: En esta vida todo depende de la dosis. No olvidemos que drogar a una persona es un comportamiento 
condenado por la ley ${ }^{17}$. El uso en esta oración de la expresión coloquial depende, cuando indica que solo se comparte lo enunciado si se dan las condiciones determinadas, ya nos pone en la pista de cómo se comportará Sílvia más adelante con las dosis solicitándole a Manel que no se deje nada de cerveza, que se la beba de un golpe. Sílvia es farmacéutica y está rompiendo con el aspecto de la cortesía relacionado con la ruptura de la imagen social que debería dar (el juramento hipocrático, la idea del deber social del farmacéutico, etc.).

Berta vuelve a declarar sus dudas, un acto de habla expresivo, con la locución verbal de tipo coloquial Tener claro. Como hemos comentado en líneas anteriores sus dudas manifiestas se vincularán a su comportamiento en líneas posteriores. Después de leer la obra, además, uno comprende que Berta es de los personaje más "reales" de la obra o, por salvedad, el que menos miente. Además, podemos pensar que la mentira de Berta es la de mayor calidad humana pues lo hace para saber si su novio aceptará la responsabilidad de criar a su hijo.

Finalmente Sílvia quiere atajar sus dudas con varias frases dignas de un análisis pragmático: Querías una solución. Aquí la tienes. Estás preñada. Preñada de un tipo del que, en el fondo, no te fías. Quieres saber lo que tiene dentro de la cabeza. Ésta es la manera. La intención de Sílvia es clara: ya no hay vuelta atrás. Es ahora o nunca. En primer lugar, a través del pretérito imperfecto como acción en el pasado, Sílvia se descarga de toda responsabilidad acusando a su amiga de manera soslayada de que si han llegado a esta situación fue por la desesperación de Berta. Entendemos que había desesperación por el plan elegido, entendemos que antes se barajaron varias estrategias y todas tuvieron menos pros que contras para terminar eligiendo la que preveían más óptima: drogar a su novio con la llamada informalmente "droga de la verdad". En este uso del imperfecto se sustrae también un reproche de Sílvia a su amiga (podemos imaginar a Berta rogándole a Sílvia una solución e incluso siendo ella la que planteara la posibilidad de usar la droga aprovechando la profesión de su amiga y la facilidad para sustraer medicamentos sin levantar sospechas).

\footnotetext{
${ }^{17}$ En 2017 se condenó en España por primera vez a un hombre por haber drogado a su ex mujer con esta droga. La pena fue de "47 días de trabajos en beneficio de la comunidad por un delito de lesiones en el ámbito familiar. Además, no podrá acercarse ni comunicarse con la víctima durante dos años y tendrá que pagarle 100 euros en concepto de indemnización por los daños sufridos". (Extraído de:

$<$ https://elpais.com/politica/2017/02/03/actualidad/1486119029_869785.html>; [Consulta realizada el 19- 7- 2020]).
} 
Después, en la segunda frase, para darle mas fuerza a su acto de habla y por economía de habla, Sílvia omite el sustantivo solución. Sin embargo, hay también una declaración de que ya no se pueden echar atrás: con el uso del adverbio demostrativo de inmediatez, de tipo deíctico que marca el contexto físico de cercanía, Sílvia está dándole a Berta una referencia: ella como hablante hace partícipe al oyente Sílvia para identificar determinada entidad, es decir, la solución la tienes aquí tanto físicamente -la droga- como vitalmente -ésta es la solución a tus problemas-. Por otro lado, la referencia deíctica proporciona un contexto que se consolida con el empleo del presente de indicativo como acción manifestada en el momento de la enunciación. Es, por último, una conminación de Sílvia a su amiga de que confíe: acto de habla directivo y expresivo a la vez. Esta justificación viene seguida de una frase que continúa con un marco deíctico preciso: Estás preñada. El adjetivo, aunque viene del latín pragenatus, tiene un sentido más coloquial que los formales embarazada o encinta. Es llamativo como el adjetivo preñada, culto en años anteriores, ahora tiene mayor uso en registros cercanos a lo coloquial. La perífrasis de estar + participio equivalente a una acción resultativa se presenta como una causa de fuerza mayor para una consecuencia extraordinaria (drogar a Manel).

La siguiente frase (Preñada de un tipo del que, en el fondo, no te fías.) comienza con la repetición del adjetivo en posición prenominal omitiendo el verbo estar de la perífrasis por la economía e impacto del argumento a los que nos hemos referido antes. Esta repetición de adjetivos de forma seguida en ambas frases se relaciona, desde un punto de vista de la entonación, con el proceso denominado afijación afectiva, que sucede, en este caso, a través de la reduplicación léxica, aportando robustez a la entonación enfática. Luego, la selección del sustantivo coloquial tipo, para referirse a individuo, le da a Berta mayor convicción en que, aunque sea un acto delictivo, drogar a Manel no es tan grave como lo sería drogar a una persona con importancia social, familiar, cultural, política, etc. Tipo se acompaña de la oración de relativo introducida por la preposición de que contempla una relación anafórica con un contenido léxico muy esclarecedor: Berta se ha quedado embarazada de un hombre en el que no confía y Sílvia tiene la confianza, y la certeza, de poder decírselo. Es, de manera manifiesta, un tipo. Se potencia entonces el aspecto de haber planeado semejante plan con la burundanga. La oración se acompaña de la locución adverbial en el fondo que significa en realidad y da, de nuevo, mayor fuerza a los argumentos de Sílvia para convencer a Berta de que lo que están haciendo es un pequeño mal a cambio de un bien mayor e imprescindible: saber si Manel se va a ocupar del futuro bebé. 
El diálogo gira, en suma, en una cuestión de confianza: la desconfianza de Berta en el plan y en su novio; y la confianza de Sílvia en el plan y también desconfianza en Manel. Terminamos con las dos últimas frases: Quieres saber lo que tiene dentro de la cabeza. Ésta es la manera. El uso de la perífrasis querer + infinitivo en segunda persona del singular plantea un acto de habla desiderativo del que, repetimos, recaen o recaerán las culpas en Berta como la última ejecutante del plan. Sílvia consigue finalmente convencerla. La concatenación de diferentes argumentos ha podido con la resistencia de Berta. Pensemos también en la cuestión de la supervivencia: tanto Berta como Sílvia se juegan mucho en esta situación. Puede darse la posibilidad de que Sílvia tenga que salir del domicilio si finalmente Berta decide confiar en Manel pues la crianza de un niño es un acto extraordinario que conlleva mucha paciencia y buen humor. ¿Será Sílvia capaz de soportar eso, teniendo en cuenta que no es su hijo y que además no tiene en muy buena estima a Manel? De Berta no hace falta explicar el por qué de la importancia de la supervivencia en esta situación que está viviendo. Termina Sílvia su intervención con otra referencia deíctica espacial a través del pronombre demostrativa ésta que supone la guinda de toda la defensa que ha realizado anteriormente: Ésta es la manera.

\section{Conclusión}

En unos pocos ejemplos seleccionados de tan solo dos obras de teatro contemporáneas escritas en castellano hemos encontrado infinidad de relaciones del uso del diálogo para crear realidades pragmáticas y viceversa. Es decir, el diálogo crea pragmática y la pragmática lo crea a él de forma indistinta. Hablar es hacer, como decía, en la referencia que ya hemos comentado anteriormente, el maestro Gutiérrez Ordóñez. Hemos demostrado que la creación literaria de obras dramáticas contemporáneas en español puede estar muy vinculada a la pragmática dialógica. Los dramaturgos sin tener por qué ser grandes especialistas titulados en el campo lingüístico sí lo son de facto a la hora de crear sus piezas. Es decir, saben cómo funciona el lenguaje y las posibilidades que semejante recurso de la comunicación humana posee. Imaginamos que en toda obra de teatro contemporánea escrita en español que seleccionemos podremos encontrar rastros de estas relaciones pragmáticodialogares profundas. Puede ser, incluso, que las obras escritas con mayor calidad sean las que tengan más ítems de estas relaciones. Por otro lado, existen numerosos estudios que tratan la perspectiva pragmática de estas obras literarias pero, y esta cuestión ha de analizarse, la mayoría desde un punto de vista 
semiótico. El análisis se realiza recurrentemente desde un punto de vista espectacular y esto es óptimo. Sin embargo, faltan más análisis que estudien con profundidad la pragmática dialógica desde un punto de vista exclusivamente lingüístico. Con nuestra pequeña muestra hemos intentado aportar nuestro grano de arena pero sabemos que quedan por cumplirse en relación con esta cuestión retos apasionantes. Entre otros retos de interés desde el punto de vista pragmático señalamos una ampliación del estudio de los marcadores discursivos y de referentes deícticos con mayor amplitud.

\section{BIBLIOGRAFÍA}

Anscombre, J. C. y Ducrot, O. (1994). La argumentación en la lengua. Madrid: Gredos. Austin, J. L. (1962). Cómo hacer cosas con palabras. Barcelona: Paidós.

Bobes Naves, M.C. (1992): El diálogo. Estudio pragmático, lingüístico y literario. Gredos, Madrid. Escandell, V. (2005). Introducción a la Pragmática. Ariel Lingüística, Barcelona.

Grice, H.P. (1975). Logic and Conversation. En Cole P. y J. L. Morgan (1975), pp. 41-58.

Gómez Torrego, L. (2009). Perífrasis verbales. Ed.: Arco Libros, Madrid.

Gómez Torrego, L. (1999). Los verbos auxiliares. Las perífrasis verbales de infinitivo. En Bosque, I. y Demonte, V. (eds.), Gramática descriptiva de la lengua española 2, Madrid, Espasa Calpe, pp. 3323-3388.

Gutiérrez Araus, M.L. (2014). Gramática y pragmática en el uso del verbo. Monográficos Lingüística en la Red (Linred). Disponible en: $<$ https://ebuah.uah.es/dspace/bitstream/handle/10017/23318/Gramatica_Gutierrez_LR_20 14_12.pdf?sequence=1\&isAllowed=y> [Consulta realizada el 8-6-2020].

Gutiérrez Ordóñez, S. (2015). "Sintaxis y pragmática. En M. Popova (Compiladora): Aktualni tendentsii $v$ razvitieto na pragmatikata y cognitivnata lingvistika, Editorial Universitaria «Sv Kliment Ojridski», Sofía, 2015, pp. 15-34.

Gutiérrez Ordóñez, S. (2005). Ejercitarás la competencia pragmática. En en Actas del XIV Congreso Internacional de ASELE, Oviedo, 2005, pp. 25-44.

Gutiérrez Ordóñez, S. (1986). Observaciones sobre el estilo directo en español. En Estudios humanísticos, Filología, № 8. Ed. Área de Publicaciones de la Universidad de León, 1986, pp. 23-38.

(2014). Juramento Hipocrático del Farmacéutico. Universidad Miguel Hernández, Alicante, España.

Levinson, S. C. (1989). Pragmática. Barcelona: Teide.

Lyons, J. (1997). Semántica Lingüística: Una Introducción. Barcelona, Paidós.

Moliner, M. (2007). Diccionario del uso del español. Ed.: Gredos. Madrid.

Real Academia Española (2011). Nueva Gramática de la lengua española.

Real Academia Española: Diccionario de la lengua española, 23.a ed., [versión 23.3 en línea]. $<$ https://dle.rae.es> [14- V- 20].

Real Academia Española (2005). Diccionario de la lengua española. Espasa Calpe, Madrid. 
Regueiro Rodríguez, Ma L. (2004). Lenguaje verbal y lenguajes no verbales en la comunicación humana. Relaciones. En Lengua y Literatura. Temario para Profesores de Secundaria y Bachillerato, Madrid, Magister. Capítulo 4.

Reyes, G. (1995). El abecé de la Pragmática. Arco- Libros, Madrid.

Searle, J. (1965). ¿Qué es un acto de Habla? En Valdés Villanueva, L. M., pp. 431-448.

Vygotski, L.S. (1982). Pensamiento y lenguaje. En L. S. Vygotski (Ed.), Obras escogidas II. Madrid: Aprendizaje Visor.

Yule, G. (2008). El lenguaje. Akal, Madrid.

\section{Textos literarios}

Galcerán, J. (2011). Burundanga. Ed.: Catalan Drama.

Messiez, P. (2019). El tiempo que estemos juntos. Ed.: Continta me tienes. Madrid. 
